\title{
"Veronica and Betty are Going Steady!": Queer Spaces in the Archie Comics
}

\author{
JEFFERY P. DENNIS
}

Jeffery Dennis (jdennis@fau.edu) completed a master's degree in English and American Literature from Indiana University and a doctorate in Sociology from SUNY Stony Brook. He has taught at UCLA, USC, and the University of Notre Dame and is currently an Assistant Professor of Sociology at Florida Atlantic University. His work has appeared in The Journal of Comparative Ethnography, The International Journal of Gender and Sexuality, The Journal of Homosexuality, and elsewhere.

\section{Introduction}

$\mathrm{P}$ erpetually befuddled teenager Archie Andrews first appeared in Pep Comics \#22 (Dec. 1941), a back-of-the-book supporting feature modeled after the Henry Aldritch radio character, but by 1945 he had become so popular that publisher John Goldwater initiated an all-Archie lineup, and changed his company's name from MLJ to Archie Comics. In the half century since, Archie and his small world of friends and foes, teachers and parents, have infused almost every genre of popular culture, including radio and television programs, toys, novels, instructional materials, religious tracts, popular music, and even a Broadway musical; but comic books remain the mainstay of the Archie empire, especially in Canada, where $30 \%$ of the comic books are sold (Norton). Although the main Archie characters are teenagers, eternally seventeen, most consumers are preteens, children between the ages of six and twelve who, generation after generation, look for glimpses of their future selves in the archetypal simplicity of Riverdale; thus, Archie comics have been emblematic of teenage life for millions of preteens. 


\section{6 / Dennis}

At first glance, the Archie comics appear consistently to present a raucous, aggressive heterosexual practice as natural, universal, and eminently more important than other pursuits or interests. Consequently, we would expect that the archetypal simplicity of Riverdale - what Charles Philips calls "an idealized picture of teenage life that we all recognize but none of us quite lived" (8) would eliminate those who do not fit into hegemonic patterns of heterosexual identity and desire, that Archie's perennial conundrum of selecting Betty or Veronica for the big dance would be meaningless or oppressive to those who would prefer to see Archie choosing Jughead, and Betty and Veronica choosing each other. However, a close reading and content analysis of select comic book stories from the 1950 s to the present reveals that attempts to espouse universal heterosexual desire fail, that discourses presenting heterosexual liaisons as the sole goal of human existence are unstable and contradictory, and that sometimes same-sex desire is acknowledged, permitted, and even celebrated.

\section{Resources and Theoretical Background}

For decades, an "Archie comic" meant a slim, flat, 32-page publication containing three or four comic stories, plus various halfor full-page gags, jokes, puzzles, advice columns, fan letters, and advertisements. The decline of the comic industry in the 1970s led to the virtual demise of such "flat comics" (though they are still available in specialty shops and via subscription), and for the last thirty years Archie has appeared primarily in "digests" or "double digests," square, thick publications, with 96 or 192 pages and up to 24 full-length stories. Sturdier and more portable than the flat comics, easily carried in a purse or pocket, and offering more stories for less money, digests are especially popular as whim purchases, sold at check-out counters at supermarkets, convenience stores, and allpurpose box-stores.

To research this project, I acquired and read 207 digests and flat comics dated between 1974 and 2001, but containing stories dating from the 1950s through the 1990s. Archie Comics vigorously reprints stories from thirty, forty, or fifty years ago without annotation or explanation, but it was possible to estimate the original publication date with relative precision. Critics frequently contend that Archie comics are frozen in a prewar small-town paradise (Barrier/Williams 
149), or that "those [comics] published in the 1990s look virtually the same as those published forty years earlier" (Wright 71). Yet, while the house style, with bold primary colors and uncluttered yet realistic backgrounds, remained more or less stable through the 1990s, there have nonetheless been many thematic changes. The 1960s, for instance, witnessed the proliferation of nonsensical sight-gags and psychedelic wordplay, while the 1970s favored high-school morality plays in a geographically-specific Riverdale and the 1980s saw a trend toward realistic dramas and adventures set beyond Riverdale. Contemporary clothing styles, slang, and references to music, movies, television, and current fads change moment by moment. Thus, Betty and Veronica swoon over "Pelvis Parsley" (Elvis Presley) in the mid 1950s, "Funzie" (Fonzie of Happy Days) in the mid 1970s; and "Boy Jonah" (Boy George) in the early 1980s. A reference to Jughead's favorite television program, Sugarlip, would narrow the date of a story to about 1959-61, the height of Sugarfoot's popularity, and a parody entitled Miami Nice can likewise be dated to 1986-88, when Miami Vice was among the top twenty network programs.

Any comic digest will contain a jumble of fifty years of pop culture, juxtaposing Liberace and the Backstreet Boys, The Ed Sullivan Show and MTV's The Real World. But no matter the publication dates and pop culture references, one theme remains constant, and is even promoted as the truth of human experience: Archie will always spend Saturday night with Betty or Veronica. They may go to a sock hop, a disco, or a rave, but there will always be Saturday nights, always dates, always boys and girls coming together to celebrate their heterosexual destiny. The Archie comics appear to paint heteronormativity in bold colors.

Michael Warner coined the term heteronormativity to refer to the practice of organizing patterns of thought, basic awareness, and raw beliefs, around the presumption of universal heterosexual desire (xi). Heteronormativity differs from heterosexual desire in that heterosexual desire refers simply to the desire of persons of different sexes, without necessarily denying the valid existence of same-sex desire, whereas heteronormativity attempts to eliminate same-sex desire from what can be displayed, discussed, or even conceived. It infuses the very epistemology of desire until the term "man" is meaningless unless it includes "desiring women," and "woman" is meaningless unless it includes "desiring men" (cf. Richardson). 
But the project of heteronormativity is doomed to failure. In her famous Epistemology of the Closet, Eve Kosofsky Sedgwick maintains that "heterosexual" can only be constructed in opposition to "homosexual," producing a binarism central to the whole of recent Western philosophy. And even when desire must be submerged into subconsciousness and identities closeted to the point of invisibility, a cultural product is still "structured like a dream, a network of representations that encodes wishes and fears, projections and identifications" (Garber 9). In the arena of cultural analysis, we can locate the wishes and fears, the instabilities and anxieties surrounding the project of heteronormativity, and therein sometimes locate irruptions of same-sex desire. Such poststructuralist and postmodern thinking informs my reading of the Archie comics.

As Roland Barthes notes, every image is polysemous, capable of practically limitless meanings. Yet the job of comic book writers and artists is to embed the image in enough context to delimit its meanings, to "fix the floating chain of signifieds in such a way as to counter the terror of uncertain signs" (Barthes 20). But signs are necessarily unfixed, especially in comic art, which is built upon inference: a few loops and squiggles, a few dialogue balloons, must suffice to establish that this figure named "Archie" is human, male, and a teenager. Anything more subtle must be inferred. "I'm practically a blank slate," a comic book character notes; "It would never occur to you what my politics are, or what I had for lunch" (McCloud 37). Or, for that matter, with whom he is in love. In order to infer that Archie is interested in Veronica, for instance, we must depend upon intertextuality, our "recognition" of elemental bonds, desires, identities, relationships, and social roles derived from other texts in the genre.

Alexander Doty finds discourses of lesbian desire between the female duos on the shows I Love Lucy and Laverne and Shirley that are present not in the script nor even necessarily in the actors' intentions, but in the dynamics of the interactions themselves, in "a place beyond the audience's conscious 'real life' definition of their sexual identities and cultural positions" (15). Likewise, while some comic characters have been self-identifying as gay for decades (Franklin), it is not necessarily incumbent on them to do so. In a comic story, an incongruity in language, an incongruity in style, or the dynamics of homosocial interaction may allow for a queer reading 
of a text (see Doty 13). The humor that underlies most Archie stories, derived through irony, parody, intertextual references, and "exaggeration, artifice, and extremity" of camp (Bergman 4), is particularly amenable to illuminating the failure of the heteronormative project and suggesting possibilities of same-sex desire. I call these possibilities "queer spaces," since they occur usually without anyone explicitly affirming a gay or lesbian identity and often within a heteronormative ideological framework in which such identities are assumed not to exist.

To locate "queer spaces" in Archie comics, I looked beyond the facade of homosociality for three major textual anomalies that can suggest the presence of same-sex desire: plots driven by a character's desire to meet, maintain a relationship with, or rescue someone of the same sex; interactions between characters of the same sex that use gestures, body placement, or vocal cues usually restricted to depictions of heterosexual desire; and characters who fail to express heterosexual desire. I also looked for "gay vague" characters, those who display mannerisms or social interests stereotypically assigned to gay or lesbian persons, regardless of their heterosexual practices (Wilke).

\section{Creating the Archie Universe: Up to the Mid 1960s}

By 1956, when Dan DeCarlo became managing editor of Archie Comics, the comic book industry was recoiling from the charges made in Fredric Wertham's book Seduction of the Innocent (1954), which accused them of promoting sexual hedonism, violence, and "homosexuality" (Wright 161). At the same time many social institutions, including the mass media, medicine, and education, continued to contribute to discourses that constructed "the homosexual" as a scourge of humankind and a special threat to homosocial masculinity (Terry 321-28). In response, DeCarlo eliminated the often risqué sexual situations of the comic books of the 1940s (Pustz 110) and authorized stories in which Archie, Reggie, Jughead, Betty, and Veronica functioned as a group of friends rather than as sexually polarized and potentially suspect "pals and gals." Robert J. Corber notes that texts of the 1950s are "grounded in a masculinist understanding of the needs and desires inspired by the American dream," especially economic and political dominance through homosocial competition or cooperation (29). Thus, Archie, 
though still swooning over girls, is equally concerned with cars, sports, and male buddies, and several characters engage in little or no heterosexual practice: Dilton, a brain in a Lord Fauntleroy costume; Reggie, a brash practical joker obsessed with 'getting' Archie; Moose, who uses his steady girlfriend as little more than a means to exhibit dominance over other boys; and especially Jughead. Stories that did involve disputes over who was going to take whom to the big dance were often framed as avenues for masculine posturing or homosocial bonding. The frame of homosocial bonding, of course, applies also to the female figures. When Betty asks Veronica "What do you find most attractive about Archie?" she responds immediately, "You!" ("Ladies Man" 1). ${ }^{1}$ That is, Veronica's interest in Archie is not predicated upon heterosexual desire, but upon the fun of competing with Betty.

The character Jughead is the most blatant example of the failure of early Archie comics to maintain the pretense of universal heterosexual desire. Jughead spent the 1940s as a sexist "womanhater," forever articulating disgust over his pals' heterosexual interests. As a member of the supposedly desexualized gang of the 1950 s, however, he necessarily became more egalitarian. He socialized with girls regularly, and grew especially close to Betty, giving her endless advice on how to win Archie's affection in the tradition of the 'best girlfriends' of the heroines of girls' comics. It became clear during the 1950 s that he did not hate women at all he simply did not care to date them. The absence of heterosexual practice - and a boy becoming the best source of girl-advice on boys - creates a queer space that challenges the presumption of universal heterosexual desire. Nonetheless Jughead's friends presume that his woman-hating is merely a temporary occlusion of his perceptual capacity - after all, he is constantly drawn with his eyes closed, 'blind' to the world around him. When he finally opens his eyes and discovers how wonderful girls really are, he will concede to his heterosexual destiny. As Archie states: "sooner or later every male sees the light" ("Artist's Choice" 1).

Similarly, a running gag in the Josie supporting stories

${ }^{1}$ Archie comics do not have sequential page numbers, and only since the mid 1990s have they given production credits. I can therefore cite the Archie stories only by title and date. 
(precursors of the 1970s Josie and the Pussycats) had every teenage boy who encountered the buxom blonde Melody distracted to the point of idiocy, crashing into things, falling into open manholes, crashing their cars, and so on. But in "See No Evil," Melody is astonished when a boy on the beach pays no attention to her. The other boys laud him as a hero. "Did you ever see such a display of sheer self-control!" they cry. "He sure ain't human!" "No guy living can resist Melody!" (7). They never suggest that the boy may not find girls attractive, just that he has sufficient self-control to reign in his overpowering lust. It turns out that he has merely misplaced his glasses, so he is 'blind.' Failure to express heterosexual desire is again associated with ignorance, with 'not seeing' and 'not knowing.' Like Jughead, this boy soon 'opens his eyes': he finds his glasses, then takes one look at Melody and self-destructs with lust. While some young readers in the 1950 s would accept such solutions to the 'problem' of the necessity of affirming heterosexual desire, others would surely identify with the unnamed boy's apparent initial 'lack' of interest, thus tacitly opening a potentially queer space.

\section{Compulsory Heterosexuality: The Mid 1960s to the Mid 1980s}

The sexual revolution of the late 1960s and 1970s saw an increasing challenge to the presumed normalcy of hegemonic gender and sexual practices through the women's movement, the various free love and group marriage experiments, and gay rights / gay pride movements. In reaction, Archie's heterosexual practice during the late 1960s and 1970s skyrocketed into absurdity. Ordinarily sensible and level headed, he dissolved into a slurry of testosterone at the merest sight of the girls whose bodies were beginning to fill the foreground of the comic panels. Archie pursued sports, cars, hobbies, and future careers no longer merely for their own sake, but for their efficiency in getting girls. If anyone commented upon the chaotic, often destructive intensity of his passion, he countered that to be "girlcrazy" was the natural male condition. In "The Unknown Equation," he begins with "the basics": "girls exert an obvious attraction on us boys, right?" (1).

Rarely were there comments: more often Archie's friends and parents assumed that the character's monomaniacal interest in girls was eminently sane, that the pursuit of the elusive heterosexual kiss was the only viable goal in life. In "The Andrews Family Tree," 


\section{2 / Dennis}

Dilton recounts stories of Archie's ancestors. They all just missed brilliant scientific discoveries because of their obsessive interest in girls - they failed to notice the apple falling because they were busy flirting, or they pulled the kite down from the thunderstorm to flirt more effectively. "I feel sorry for your ancestors," Dilton concludes. "They were a bunch of losers." Archie retorts, "And I feel sorry for poor Dilton! He can't tell us winners from the losers!” (8).

Also in the 1960s and on, we see an expansion of the parameters of universal heterosexual desire: characters who were excused from displaying heterosexual interests during the 1950 s were now required to bounce about in jubilation, shouting "Va-va-voom!" (the standard Archie exclamation of sexual arousal) whenever they encountered a person of another sex. Overt, intense expressions of heterosexual interest were deemed necessary for full communion with human society. When Dilton begins to express heterosexual interest in "The New Dilton," his friends are relieved: "Dilt has joined the pack ... he really is one of us" (6). During the 1970s, Dilton dropped his pedantic demeanor (though remaining intelligent) and agonized endlessly over his failure to acquire sufficient girls. Reggie began dating frequently and ardently. And even though Moose had had a steady girlfriend for nearly twenty years of comic book stories, he was still criticized for being insufficiently intense in his expression of heterosexual interest: in "Potions of Love," Midge complains that Moose is "girl-shy! No confidence! Afraid to make a move!" (4).

During the 1950s, Archie Comics introduced a number of supporting strips featuring bratty preteen characters who made life miserable for their parents or teenage siblings. During the 1970s, these figures were dropped with the exception of Li'l Jinx, who became as obsessed with heterosexual practice as the characters in the main Archie stories. Ten-year old Jinx was torn between two boyfriends, Mort and Greg, and attempted to keep them both out of the clutches of glamorous, man-hungry Gigi. Likewise the rotund and crass Charlie Hawse claimed a lack of heterosexual interest during the 1970s, but eventually even he sees the error of his ways. In "Dear Diary," originally published shortly after the movie Blue Lagoon (1981), Charlie reads a romantic fantasy in Mort's diary and concludes that he knows "Brook Shield" (actress Brooke Shields). Hearts of heterosexual desire explode above his head and, panting, he exclaims to Mort "You've got to introduce me to her!" (2). 
Only Jughead was excused from the necessity of expressing heterosexual interest during the $60 \mathrm{~s}$ and $70 \mathrm{~s}$, but his friends were less likely to conclude that he was simply blind and would one day encounter his heterosexual destiny. His friends specifically defined his lack of interest in girls as a 'failure,' an abnormality to be tolerated at best. Furthermore, his 'failure' was, for the first time, associated with a desire for boys; that is, he formed same-sex bonds in those situations in which his peers would form heterosexual bonds. Again, Jughead's behavior creates the possibility of same-sex desire and opens queer space. In "The Loner," Jughead is invited to participate in a heterosexual double date, but he exclaims "I hate double dates! Especially with girls!" (1). Although he purports to be stating nonsense (as in his catch phrase, "Half of the lies they tell about me aren't true"), at least syntactically his special dislike for dates with girls implies that other sorts of dates are possible.

In "There's This Girl, See?" Jughead's friends assume that he needs some money to go on a date with a girl. His friends assume that he wants to finance a date with her. They joyfully shout "[that's] the first sign of normalcy in that weirdo" (2) and take up a collection. It turns out that the girl has failed to pay back a loan, which he needs to finance a 'date' with a boy (who is not named, since the Archie universe frowns on naming new characters). The last panel of the story shows Jughead happily walking away with his arm around the boy, initiating his 'date' while his friends bang their heads together in frustration. Jughead's behavior meets the Archie universe definition of the term "date" in every detail: a social event for two people, during which the one who pays puts an arm around the one who does not.

This presumed universality of (hetero)sexual desire, when coupled with the failure to follow it through, allows for other queer spaces in the Archie stories of the 60s and 70s. In "Common Ground," the gang is at the beach, when a boy named Cliff zooms up on a dune buggy. This will be no ordinary encounter: Archie characterizes him as "crazy," underscoring his potential danger physical, social, or ontological. Cliff invites Veronica for a ride and, oblivious to the danger, she accepts. In the Archie universe, boys issue invitations for rides only when they want to "make time," that is, initiate a romance with someone else's girlfriend. But after a rather strenuous circuit of the beach, Cliff dutifully drops Veronica off. Then 


\section{4 / Dennis}

he turns to Reggie and asks, "How about you?" (5). Reggie eagerly accepts, and the story ends with the two boys riding off together. In this story, is a ride supposed to be just a ride, with no romantic implications? If so, why did Cliff earn the description "crazy" that signals a threat to Archie's relationship with Veronica? Or perhaps he was trying to "make time" with Veronica after all, and now he has moved on to Reggie.

In "Tough Bluff," Betty and Veronica find Archie's "little black book," his list of potential romantic prospects, and hope to use it to identify their rivals. To their surprise, it contains only boys' names: "Joe, Bill, Al, Tony, Moose, Reg, Mike." They sadly conclude that it is an ordinary address book - if it does not contain girls' names, then it cannot be a real "little black book." Later, Archie explains to Jughead that he deliberately filled the book with boys' names to distract the girls from his real romantic interests. So what is the "tough bluff"? What is he distracting them from? If he wants to hide a list of potential girlfriends from Betty and Veronica, it is curious that he would invent a list made up solely of boys' names. His choice of boys indicates an oddly meticulous investment into the popular convention of the "little black book." New character names are extremely rare in the Archie universe, but Archie lists five here, and in addition includes only two recognizable friends, Moose and Reg ("Reggie"). Why does he omit Dilton and Jughead? Moose and Reggie are arguably the most attractive members of the gang, and Dilton and Jughead, somewhat nerdish, are perhaps the least attractive. Archie has not filled his "little black book" with names chosen at random (for a ruse) or the names of his friends (as in an ordinary address book), but has compiled a list of boys who are either the most likely objects of someone's infatuation or simply "unknown." He has gone to a lot of trouble to hide his romantic interests, unless he is hiding them in plain sight.

\section{Universal Heterosexuality: The Mid 1980s to the Mid 1990s}

During the last half of the 1980s, the AIDS epidemic made it difficult to ignore same-sex desires and practices, even in comic books. When aging Hollywood star Rock Hudson, dying of AIDS, was revealed to be gay and dying of AIDS, many fans felt curiously betrayed: Hudson had been emblemeatic of male heterosexuality, even though rumors of 'homosexuality' had dogged his career, and many of his 
films were plotted around various hints of transgressive desire. But, as Marita Sturken states, when the revelations were made in the summer of 1985, "we had to accept the fact that many of our fundamental, conventional images [of heterosexuality] were instilled by someone gay" (151). The absent had suddenly become present, the unstated stated. Archie comics characters could no longer solve the 'problem' of lack of heterosexual desire in certain characters by invoking blindness or ignorance and deferring heterosexual destiny to a future epiphany. Even young readers would know that a boy who did not like girls might like boys, and Archie comics found that possibility intolerable.

An increasing awareness on the part of Archie comics that gay and lesbian identities exist can be seen in the increasingly blatant attempts at excluding them. Veronica talks about having "a wild old time" instead of the traditional "gay old time." The girls swoon over "Boy Jonah" (gender-bending pop star Boy George), but never describe his androgynous stage presence. They attend the "Horrible Rocky Picture Show" (The Rocky Horror Picture Show, where drag is de rigueur), but dress as Frankensteins and mummies, not as transvestite Frank N Furter and his crew.

In 1988, before any other children's medium broached the topic of HIV/AIDS, Archie comics began promoting AIDS education with a frequently reprinted ad. A somber Mr. Weatherbee stands before a blackboard while the gang, drawn considerably smaller than usual, look up from desks arranged in a semicircle. The minor character Chuck has replaced Reggie, perhaps because he is African-American and thus might appeal to a wider audience. The blackboard reads "Health Education" and then "AIDS is a serious worldwide problem that affects people of all ages in all walks of life" ("AIDS Education"). The choice of the word "problem" instead of "disease" is wise, since AIDS has had an impact on practically every human activity, from the cultural to the economic. The phrase "all ages" includes both teenagers (the Archie gang) and preteens (the comics' usual audience), but "all walks of life" simultaneously encodes and erases both gays and straights. The students look somber, almost frightened, except for Jughead, who is leaning back with a smirk. His smirk is significant. By 1988, AIDS was decimating gay communities, and gay people would have been particularly attuned to Mr. Weatherbee's presentation. But Jughead's smirk indicates that 


\section{6 / Dennis}

he does not see himself as much at risk as his fellow students, that is, as certainly not gay. It is a gesture that explains that thirty comic book years of not liking girls signified a 'healthy' shyness, certainly not same-sex desire.

During the mid 1980s, Archie Comics blatantly attempted to defuse any reading of Jughead's character as gay. In "Genesis the Beginning," Jughead is up late, when a beam of light emanates from his TV set and paralyzes him. He loses consciousness. The next morning he has received a facelift, and there is a curious masculine symbol affixed to his beanie. "I feel reborn!" he exclaims. "I have strange tingling sensations! I have a desire to talk to ... to touch ... my gosh! A girl!" (2). Reggie doesn't believe in Jughead's transformation and intensifies his evaluation of "women-hating" from mere deviation to pathology: "That boy is one sickie!" But Archie comes to his aid: "This is going to make him more normal!" (3). Further stories in the mid 1980s had Jughead, Archie, and Reggie recounting this experience over and over to practically everyone in Riverdale, and of course to every reader. In "Seeing is Unbelieving," Archie notes that Jughead had "either a close encounter or a mad nightmare, but it left him a self-confident, girl-loving, prowling wolf" (1). The "woman-hating" of the past is dismissed as shyness (though Jughead was never shy) or lack of self-confidence (though he was always the most self-confident of the group). In an open letter, managing editor John Goldwater noted that Jughead had "changed" (but failed to give any details), and invited comments about whether readers liked the old or the new Jughead better (Goldwater). The consensus was overwhelming: readers preferred the old Jughead. Nevertheless, the girl-loving Jughead prevailed during the next decade: he was involved in several passionate affairs and tempestuous love-hate relationships, and many stories made casual reference to heterosexual dates. Paradoxically, the girl-hating Jughead occasionally appeared; in "Bank Trouble," he saves an attractive female star from drowning, but refuses a kiss as a reward because he hates kissing girls. In its capsule biography of Jughead, the Archie Comics Website refers to his "rather abnormal dislike of girls" (Archie Comics Website).

Minor characters were similarly recast in the mid 1980s to avoid the implication of same-sex desire in same-sex dyads. Before 1986, Veronica's mother appeared rarely; her father, Mr. Lodge, was more 
or less a single parent. Servants came and went, depending on the need of the story, but Smithers the butler remained constant. His attachment to Mr. Lodge transcended the employer-employee relationship. Often the two were shown sitting side by side in easy chairs, cozily discussing Veronica's latest shopping spree or enjoying Archie's latest comeuppance as equals. From 1986 on, the role of Smithers decreased, and suddenly Mrs. Lodge appeared in almost every story involving Veronica's home life.

\section{Everybody's Gay: The Mid 1990s to the Present}

The 1990s saw an economic downturn in the comic book industry, with sales declining by half (Pearson/Miller), and the demise of practically every title aimed at children. Archie Comics survived and even prospered through the strategic marketing of comic digests and the hiring of a cadre of new writers, including women and people of color, introduced by editors Nelson Ribeiro and Victor Gorelick (Archie Comics Website). They reinvented Archie Comics by experimenting with style and color, exploring odd corners of the Archie universe (with such titles as "Dilton's Weird Science" and "Jughead's Diner"), and softening the more stereotypic characters (Moose became dyslexic, not stupid, and Big Ethel, shunned for decades as ugly, became simply plain, but nonetheless hip, fun, and popular). They also moved away from the mania to make every character "boy-crazy" or "girl-crazy," positing a Riverdale where teenagers enjoy a wide variety of interests. Some stories even dealt explicitly with the possibility of same-sex desire.

In "Little Black Book" (surely a reworking of "Tough Bluff"), Betty encounters an address book, assumes that it contains a boy's romantic prospects, and is surprised to find her name missing. "There's no accounting for tastes," she thinks, "I'm a much better date than Tom Cameron or Ron Cook" (2). A moment later, she concludes that it is Veronica's "little black book," thus offering a heterosexual solution to the 'problem' of romantic interest in boys. But this solution does not affirm the universality of heterosexual desire: previously, Betty took it for granted that the book belonged to a boy, that somewhere in Riverdale was a boy who dated (or wished to date) Tom Cameron and Ron Cook; her nonchalance suggests that same-sex desire is not so out of the ordinary after all. 
In "Clean Sweep," Betty notes that "every girl" wants to be swept off her feet, so Archie obliges by picking her up off the floor. Later, Jughead explains what happened by 'sweeping' Veronica off her feet. Principal Weatherbee expresses outrage over this "carrying on" (an Archie universe expression for heterosexual practice), and threatens detention for the next culprit. At that moment, Moose appears with Dilton in his arms (5). The sight of a boy 'sweeping' another boy off his feet so shocks Mr. Weatherbee that his glasses and toupee pop off, and question marks and exclamation marks appear above the students' heads. Moose explains that he is merely carrying Dilton to the infirmary after a sports injury, thereby offering a homosocial solution to the 'problem.' Again, his solution does not so much affirm heteronormativity as it leaves the question of samesex desire in circulation: if Moose does not feel at least a minimal attraction, why would he literally 'sweep' Dilton off his feet, selecting, of all the possible ways to transport an injured chum, one that maximizes intimacy and mimics a romantic gesture?

In "You've Got to Give Her Credit," written by Hal Smith, Veronica is delighted to receive some credit cards in the mail and asks Smithers the butler to "give the mailman a big kiss for me!" He replies "I beg your pardon!" embarrassed but adjusting his tie, as if kissing the mailman might indeed be a possibility. In the next sequence, Mr. Lodge, dining with a male companion at the Riverdale Country Club, exclaims "It's like they're multiplying" (3). In the foreground, a young man with black hair and a mustache grins as he wraps his arm around the shoulders of a muscular red-haired man, who is turned toward him with a dreamy expression. Although both are wearing suits, implying a business deal, they look precisely as if they are in the midst of a romantic evening. Mr. Lodge is obviously referring to Veronica's multiplying credit cards, but as our eyes are drawn to an overt same-sex couple, we cannot help but speculate on his response to the increasing visibility of gay men in North American society.

In a self-reflective postmodern twist in "Verse Than Ever," also written by Hal Smith, Veronica is aware that she is a character in a comic book, and objects to its title, Betty and Veronica. She wants to be first. She argues that Betty would be better in last place, because so many words rhyme with Betty that they could therefore create poems. As an example, she recites "Break out the confetti! Veronica 
and Betty are going steady!" Betty snarls "Watch it!" The exclamation point after "going steady" denotes that Veronica was finished with her rhyme, that she had intended a couplet, but with a look of sophisticated smugness, she adds a heterosexualizing coda "... with Freddy and Teddy" (3). Betty wheezes "Whew!" She is drenched with sweat and near collapse. The thought that they might be considered lovers has had a profound impact on her. While Veronica is unfazed and may even have intended the implication, Betty reacts with a veritable panic.

What are we to make of this sequence? Not entirely cognizant of the definitional boundaries of adult romantic relationships and friendships, children often confuse the two, ascribing romance to relationships that surely would not involve explicit erotic desire. If this sort of slippage is intended, Betty's reaction makes no sense. Instead, she must be aware that girls sometimes date girls, that she and Veronica could indeed "go steady." But still, the violence of her reaction is curious, especially given Veronica's nonchalance. An explanation may be found in Betty's longstanding characterization as an athletic type and a tomboy, at ease in the auto garages and workshops where she is gender-polarized as male; she is frequently advised that her heterosexual loves are stymied because she is too much like 'one of the guys.' Although obsessed with Archie and dating many boys, she rarely shares Veronica's giddiness about the male form. Indeed, she often demonstrates rather explicit same-sex interests. At the beach with Archie, she continuously points out attractive women: "Isn't that a pretty girl? Doesn't she have a gorgeous body?" ("Run for Your Life" 1). Certainly heterosexual women are permitted to notice other women, but such enthusiasm, especially in front of one's presumed boyfriend, seems perilously close to an acknowledgment of Betty's own desire. Perhaps the 'joke' in "Verse Than Ever" rang too true, highlighting a subtext in her relationship with Veronica that neither she nor the author could comfortably address. He immediately brings Archie on stage, and the story switches to slapstick.

\section{Conclusion}

During the last sixty years, thousands of Archie comics stories have introduced millions of children, as well as teenagers and adults, to a Riverdale where heterosexual desire supposedly informs every 
action, every thought, every plan. But every text is open, every reading is fragmentary, every hegemony is ultimately incoherent. Even the most heteronormative boy-torn-between-girls text will see same-sex desire intrude in the form of a boy who walks off with his arm around another boy, or a girl who makes a 'joke' about going steady with her best friend. We can never conclude definitively that Jughead is in love with Archie, or that he is not, or that Veronica is in love with Betty, or that she is not. The characters exist only as lines and squiggles on a page; their thoughts, their goals, their desires must be articulated through generic conventions and intertextual references. And it is in that articulation that we can find queer spaces even at Riverdale High.

\section{Works Cited}

“AIDS Education.” Jughead with Archie Digest 88 (1988).

“The Andrews Family Tree." Archie Digest 108 (1991).

Archie Comics Website. <http://www.archiecomics.com>.

“Artist's Choice." Archie Double Digest 114 (2000).

"Bank Trouble." Jughead Second Series 130 (2000).

Barrier, Michael, and Martin Williams. A Smithsonian Book of Comic-Book Comics. New York: Abrams, 1981.

Barthes, Roland. "The Rhetoric of the Image.” Studying Culture. Ed. Ann Gray and Jim McGuigan. New York: St. Martin's, 1993. 15-27.

Bergman, David. Camp Grounds: Style and Homosexuality. Amherst: University of Massachusetts Press, 1994.

“Clean Sweep.” Jughead's Double Digest 66 (2000).

"Common Ground." Betty and Veronica 167 (1969).

Corber, Robert J. Homosexuality in Cold War America: Resistance and the Crisis of Masculinity. Durham, NC: Duke University Press, 1997.

“Dear Diary.” Archie Annual Digest 49 (1986).

Doty, Alexander. Making Things Perfectly Queer: Interpreting Mass Culture. Minneapolis: University of Minnesota Press, 1993

Franklin, Morris E. III. "Coming Out in Comic Books: Letter Columns, Readers, and Gay and Lesbian Characters." Comics \& Ideology. Ed. Matthew P. McAllister, Edward H. Sewell, and Ian Gordon. New York: Lang, 2001. 221-50.

Garber, Marjorie. Symptoms of Culture. New York: Routledge, 1998. 
"Genesis — the Beginning." Jughead Jones Digest 36 (1986).

Goldwater, John. "Letter to the Readers." Jughead with Archie Digest 88 (1988).

"Ladies Man." Laugh Digest 1 (1974).

“Little Black Book.” Betty's Diary 34 (1990).

“The Loner." Jughead Jones Digest 47 (1987).

McCloud, Scott. Understanding Comics: The Invisible Art.

Northampton, MA: Kitchen Sink, 1993.

“The New Dilton." Archie 498 (2000).

Norton, Bonny. "Archie Comic Readers and Cultural Literacy." Paper presented at the Portraits of Literacy Conference, University of British Columbia, 2002.

Pearson, Lars, and John Jackson Miller. "State of the Industry 1996."

Comic Buyer's Guide 1997. Ed. Maggie Thompson and John Jackson Miller. Iola, WI: Krause. 12-30.

Phillips, Charles. Archie: His First 50 Years. New York: Abbeville, 1991.

"Potions of Love." Archie Digest 141 (1996).

Pustz, Matthew J. Comic Book Culture: Fanboys and True Believers. Jackson, MI: University Press of Mississippi, 1999.

Richardson, Diane. "Heterosexuality and Social Theory." Theorizing Heterosexuality: Telling it Straight. Ed. Diane Richardson. Buckingham: Open University Press, 1996. 1-20.

"Run for Your Life." Archie Digest 79 (1986).

Sedgwick, Eve Kosofsky. The Epistemology of the Closet. Berkeley:

University of California Press, 1990.

"See No Evil." Laugh Comic Digest 31 (1980).

"Seeing is Unbelieving." Archie Digest 79 (1986).

Sturken, Marita. Tangled Memories: The Vietnam War, the AIDS

Epidemic, and the Politics of Remembrance. Berkeley:

University of California Press, 1997.

Terry, Jennifer. An American Obsession: Science, Medicine, and Homosexuality in Modern Society. Chicago: University of

Chicago Press, 1999.

“There's This Girl, See?" Archie Annual Digest 74 (1991).

"Tough Bluff." Laugh Digest 1 (1974).

"The Unknown Equation." Archie Comics Website. <http:// www.archiecomics.com>.

"Verse Than Ever." Betty and Veronica Digest 94 (1998). 
142 / Dennis

Warner, Michael. "Introduction." Fear of a Queer Planet: Queer Politics and Social Theory. Ed. Michael Warner. Minneapolis: University of Minnesota Press, 1993. vii-xxxi.

Wertham, Frederick. Seduction of the Innocent. New York: Rinehart, 1954.

Wilke, Mike. "The Commercial Closet." <http://www. commercialcloset.com>.

Wright, Bradford W. Comic Book Nation: The Transformation of Youth Culture in America. Baltimore: Johns Hopkins University Press, 2001.

"You've Got to Give Her Credit." Betty and Veronica Digest 105 (1999). 